\title{
KEJADIAN MALARIA PADA ANAK DAN IBU HAMIL DAN PROGRAM PENGENDALIAN MALARIA DI DESA SUKAJAYA LEMPASING, KABUPATEN PESAWARAN
}

\author{
Santoso $^{1^{\star}}$, Indah Margarethy $^{1}$, Maya Arisanti ${ }^{1}$, Rizki Nurmaliani $^{1}$ \\ ${ }^{1}$ Balai Penelitian dan Pengembangan Kesehatan Baturaja \\ JI. A.Yani KM.7 Kemelak Baturaja, Ogan Komering Ulu, 32111 Sumatera Selatan, Indonesia
}

\begin{abstract}
Lampung Province is one of the areas where malaria is endemic. Districts with the highest prevalence was Pesawaran (API of $4.8 \%$ ). The sample in this study were pregnant women and children under five in the region Sukajaya Lempasing Village. The number of samples in the study were 100 pregnant women and infants. Informants for in-depth interview were Malaria program management. Results of blood sampling with RDT to get three samples of 100 samples positive for falciparum malaria. The results of microscopic examination found no positive slide plasmodium. Residents who have had a fever as much as $42 \%$. The results of the bivariate analysis to get a significant relationship between a history of fever with contact to previous malaria patients. The use of mosquito nets while sleeping it is customary society, especially pregnant women and infants to prevent mosquito bites. The malaria control that has been carried out includes spraying, larvaciding and distribution of bed nets.
\end{abstract}

Keywords: Malaria, infant, pregnant women, Sukajaya Lempasing.

\section{MALARIA INCIDENT IN CHILDREN AND PREGNANT WOMEN AND MALARIA CONTROL PROGRAM IN SUKAJAYA LEMPASING VILLAGE, PESAWARAN}

\begin{abstract}
Abstrak
Provinsi Lampung merupakan salah satu daerah endemis malaria. Kabupaten dengan prevalensi tertinggi adalah Kabupaten Pesawaran dengan API sebesar 4,8\%. Sampel dalam penelitian ini adalah ibu hamil dan balita yang ada di wilayah Desa Sukajaya Lempasing Puskesmas Hanura.Jumlah sampel dalam penelitian adalah 100 orang ibu hamil dan balita. Informan untuk wawancara mendalam adalah petugas pengelola program Malaria. Hasil pengambilan darah dengan RDT terhadap 100 sampel mendapatkan tiga sampel positif malaria falciparum. Hasil pemeriksaan mikroskopis tidak ditemukan slide positif Plasmodium. Penduduk yang pernah mengalami demam sebanyak $42 \%$. Hasil analisis bivariat mendapatkan adanya hubungan yang bermakna antara riwayat demam dengan riwayat kontak dengan penderita malaria sebelumnya. Penggunaan kelambu pada saat tidur sudah merupakan kebiasaan masyarakat khususnya ibu hamil dan balita untuk mencegah gigitan nyamuk. Pengendalian malaria yang telah dilakukan diantaranya penyemprotan, larvasidasi, dan pembagian kelambu.
\end{abstract}

Kata Kunci: Malaria, bayi, ibu hamil, Sukajaya Lempasing. 


\section{PENDAHULUAN}

Malaria masih menjadi masalah kesehatan dunia terutama di Afrika dan Asia Tenggara. Tahun 2016 World Health Organization (WHO) memperkirakan jumlah kasus malaria di dunia sebesar 216 juta. Jumlah kasus di Asia Tenggara dilaporkan tahun 2016 sebesar 14.600.000 dengan proporsi tingkat kasus malaria di wilayah ini paling tinggi adalah India sebesar $90 \%$ dan selanjutnya Indonesia sebesar 9\%, sedangkan sisanya adalah Myanmar sebesar $1 \%{ }^{1}$

Kabupaten Pesawaran merupakan salah satu daerah endemis malaria di Provinsi Lampung. Jumlah kasus malaria yang dilaporkan selama tahun 2014 sebanyak 3.033, Annual Parasite Incidence (API) sebesar 7,26\% dan tahun 2015 sebanyak 2.712 , API sebesar $6,36 \%$. Jumlah balita yang terkena malaria sebanyak 77 dan ibu hamil sebanyak 11 orang. Jumlah kematian karena malaria tahun 2015 dilaporkan sebanyak 1 orang ibu hamil. ${ }^{2}$

Kecamatan Padang Cermin merupakan daerah di wilayah Kabupaten Pesawaran yang memiliki API tertinggi tahun 2015, yaitu sebesar $170,1 \%$. Upaya pengobatan malaria telah menggunakan metode pengobatan baru, yaitu Artemisinin-based combination therapy (ACT) terhadap penderita malaria dengan konfirmasi laboratorium (pemeriksaan slide) maupun Rapid Diagnostic Test (RDT). Permasalahan yang dihadapi oleh petugas kesehatan adalah perilaku masyarakat yang sering melakukan pengobatan malaria sendiri tanpa konfirmasi laboratorium. Hal ini menghambat program penemuan dan pengobatan malaria secara rasional, efektif, dan efisien. ${ }^{3}$

Penelitian sejenis pernah dilakukan, yaitu di Kabupaten Bulukumba yang meneliti tentang penggunaan kelambu terhadap pengendalian malaria dengan populasi masyarakat yang dibagikan kelambu berinsektisida (Long-Lasting Insecticidal Nets/LLINs) di wilayah kerja Puskesmas Bonto Bahari Kabupaten Bulukumba sebanyak 1.038 orang dengan sampel 91 orang. Hasil penelitian menunjukkan bahwa 98\% penduduk yang mendapatkan kelambu menggunakan kelambu pada malam hari. ${ }^{4}$ Hasil penelitian yang dilakukan di Kabupaten Tanah Bumbu dengan populasi adalah masyarakat yang diberi kelambu LLIN's di
Desa Teluk Kepayang Kecamatan Kusan Hulu Kabupaten Tanah Bumbu sebanyak $826 \mathrm{KK}$ dengan responden 275 mendapatkan bahwa penggunaan kelambu terbukti dapat menurunkan kejadian malaria. ${ }^{5}$

Hasil analisis Riskesdas tahun 2007 mendapatkan adanya faktor pelayanan kesehatan yang berhubungan dengan kesakitan malaria, yaitu waktu tempuh ke sarana kesehatan dan pemanfaatan sarana kesehatan. Penggunaan kelambu juga berhubungan dengan kejadian malaria. ${ }^{6}$

Beberapa penelitian telah menunjukkan bahwa terdapat hubungan antara pemakaian kelambu dengan risiko kejadian malaria. Namun berdasarkan data pembagian kelambu dan data kasus malaria yang dilaporkan oleh Dinas Kesehatan Kabupaten Pesawaran menunjukkan adanya permasalahan yang perlu diteliti lebih lanjut, yaitu tentang perilaku masyarakat sebelum tidur. Penduduk berisiko telah mendapat kelambu berinsektisida, tetapi masih dapat terserang malaria, hal ini diketahui dari data KLB malaria yang terjadi pada tahun 2013 dengan proporsi anak yang terserang malaria sebesar $30 \%$ dan terdapat ibu hamil yang meninggal karena malaria.

Ibu hamil penderita malaria memiliki potensi untuk menularkan malaria secara langsung ke janin yang dilahirkan (malaria kongenital). Bayi yang baru lahir juga dapat terkena malaria neonatal melalui gigitan nyamuk vektor. Malaria pada bayi sangat berbahaya karena risiko terjadi kematian lebih tinggi. ${ }^{7}$ Penelitian ini bertujuan mengidentifikasi ibu hamil dan balita yang menderita malaria berdasarkan pemeriksaan dan faktor risiko malaria pada anak dan ibu serta upaya pengendalian malaria yang telah dilakukan dinas kesehatan dan puskesmas.

\section{METODE}

Penelitian ini telah mendapatkan persetujuan etik (ethical approval) dari Komisi Etik Badan Litbangkes Nomor: LB.02.01/5.2/KE.169/2016, tanggal 5 April 2016.

Penelitian ini telah dilakukan selama 6 bulan (Februari-Juli 2016) di wilayah Puskesmas Hanura, Kabupaten Pesawaran, Provinsi Lampung. Jenis penelitian ini adalah penelitian terapan non intervensi dengan desain cross-sectional survey. 
Populasi penelitian adalah seluruh penduduk yang ada di Kabupaten Pesawaran, Provinsi Lampung, dengan target populasi adalah penduduk yang tinggal di wilayah Puskesmas Hanura dan pernah mendapatkan kelambu berinsektisida (LLIN's). Pemilihan Puskesmas Hanura sebagai lokasi penelitian karena di wilayah puskesmas ini angka kejadian malaria dilaporkan paling tinggi dan pernah terjadi KLB dengan kematian ibu hamil. Jumlah kasus malaria dengan pemeriksaan yang dilaporkan selama tahun 2015 di Puskesmas Hanura sebanyak 2.281 dengan kasus tertinggi ditemukan di Desa Sukajaya Lempasing sebanyak 1.170 (51\% dari total kasus), dengan API sebesar 170,1\%. Sampai dengan bulan Mei 2016 jumlah kasus malaria terkonfirmasi yang dilaporkan di Desa Sukajaya Lempasing sebesar 488 orang. ${ }^{3}$

Jumlah sampel penduduk yang dibutuhkan untuk menentukan angka malaria dalam penelitian ini dihitung berdasarkan jumlah sampel minimal dengan rumus ${ }^{8}$

$$
\mathrm{n}=\frac{z_{1-\frac{\alpha}{2}}^{2} \mathrm{P}(1-\mathrm{P}) \mathrm{N}}{\mathrm{d}^{2}(\mathrm{~N}-1)+z_{1-\frac{\alpha}{2}}^{2} \mathrm{P}(1-\mathrm{P})}
$$

$\mathrm{n} \quad=$ Jumlah sampel yang dibutuhkan (73)

$Z_{1-\alpha / 2}=$ Standar skor yang dikaitkan dengan taraf nyata diinginkan

$\mathrm{P} \quad=$ Proporsi yang diharapkan $(0,05)$

$\mathrm{N} \quad=$ Jumlah populasi (417.732)

$\mathrm{D}=$ Nilai presisi absolut yang dibutuhkan (5\%)

Berdasarkan perhitungan besar sampel minimal yang dibutuhkan sebesar 73 orang anak/ibu hamil. Jumlah sampel ditambah $10 \%$ untuk antisipasi drop out sehingga jumlah sampel menjadi 80 .

Pemilihan sampel dalam penelitian ini menggunakan purposive sampling. Sampel pertama yang dipilih adalah rumah tangga yang memiliki ibu hamil atau balita di rumah terdekat dengan penderita malaria yang meninggal dari laporan sebelumnya. Sampel selanjutnya dicari ibu hamil dan balita lainnya yang tinggal di sekitar rumah penderita sampai jumlah sampel mencukupi sampel minimal. Proporsi antara ibu hamil dan balita tidak diperhitungkan dalam mencukupi jumlah sampel minimal.

Selain pengambilan darah juga dilakukan wawancara mendalam terhadap pengelola malaria Dinas Kesehatan Provinsi Lampung, Dinas Kesehatan Kabupaten Pesawaran, dan Puskesmas Hanura. Wawancara bertujuan untuk mendapatkan informasi tentang kegiatan program penanggulangan malaria khususnya di wilayah Puskesmas Hanura yang merupakan daerah endemis tertinggi dan pernah terjadi KLB malaria dengan kematian ibu hamil.

\section{HASIL}

\section{Pemeriksaan dan Karakteristik Sampel}

Pemeriksaan darah jari dilakukan terhadap 100 penduduk di wilayah Puskesmas Hanura. Jumlah sampel minimal dalam penelitian ini adalah 80 responden, tetapi dalam penelitian ini dibulatkan menjadi 100 responden. Penduduk yang diperiksa terdiri dari 64 balita (64\%) dan 36 ibu hamil (36\%). Hasil pemeriksaan mendapatkan tiga sampel positif hasil pemeriksaan RDT dengan angka parasit sebesar $3 \%$. Hasil konfirmasi laboratorium dengan pemeriksaan mikroskopis tidak ditemukan slide positif malaria (Tabel 1).

Tabel 1. Distribusi Hasil Pemeriksaan Malaria Berdasarkan Kelompok Responden

\begin{tabular}{lccc}
\hline \multicolumn{1}{c}{ Kelompok } & $\begin{array}{c}\text { Positif } \\
\text { n (\%) }\end{array}$ & $\begin{array}{c}\text { Negatif } \\
\text { n (\%) }\end{array}$ & $\begin{array}{c}\text { Jumlah } \\
\text { n (\%) }\end{array}$ \\
\hline Balita & $1(1,6)$ & $63(98,4)$ & $64(100)$ \\
Ibu Hamil & $2(5,6)$ & $34(94,4)$ & $36(100)$ \\
\hline Total & $3(3,0)$ & $97(100)$ & $100(100)$ \\
\hline
\end{tabular}


Umur ibu hamil yang paling muda hasil penelitian ini adalah 16 tahun dan umur paling tua adalah 46 tahun. Selain dilakukan pemeriksaan darah juga dilakukan wawancara singkat terhadap ibu hamil dan orang tua atau wali dari balita tentang riwayat demam, lama tinggal, dan riwayat kontak dengan penderita malaria. Hasil wawancara singkat disajikan dalam Tabel 2 berikut:

Tabel 2. KarakteristikResponden Berdasarkan Riwayat Demam, Riwayat Kontak, dan Lama Tinggal

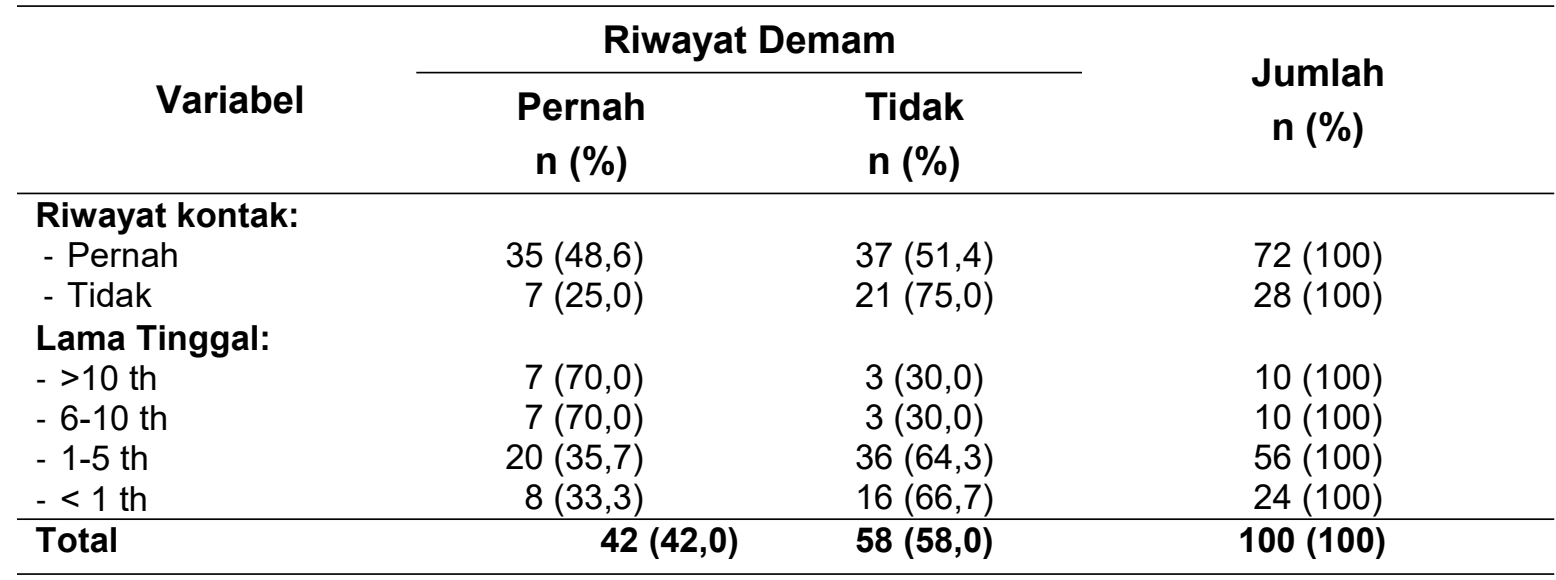

\section{Perilaku yang berhubungan dengan kejadian malaria}

Analisis hubungan antara perilaku dengan kejadian malaria tidak menunjukkan adanya hubungan yang signifikan, hal ini karena jumlah penderita positif dari hasil pemeriksaan RDT hanya tiga sampel. Selanjutnya dilakukan analisis hubungan antara riwayat demam yang merupakan gejala klinis malaria dengan perilaku. Hasil analisis disajikan dalam Tabel 3 berikut

Tabel 3. Distribusi Hubungan Perilaku Responden dengan Riwayat Demam pada Responden di Wilayah Puskesmas Hanura Tahun 2016

\begin{tabular}{|c|c|c|c|c|c|c|c|c|}
\hline \multirow{3}{*}{ Perilaku } & \multicolumn{4}{|c|}{ Riwayat Demam } & \multirow{2}{*}{\multicolumn{2}{|c|}{ Total }} & \multirow{3}{*}{$\begin{array}{c}\text { OR } \\
95 \% \mathrm{Cl}\end{array}$} & \multirow{3}{*}{$\begin{array}{c}P \\
\text { value }\end{array}$} \\
\hline & \multicolumn{2}{|c|}{ Pernah } & \multicolumn{2}{|c|}{ Tidak } & & & & \\
\hline & $\mathrm{n}$ & $\%$ & $n$ & $\%$ & $\mathrm{~N}$ & $\%$ & & \\
\hline $\begin{array}{l}\text { Penggunaan kelambu: } \\
\text { - Tidak } \\
\text { - Ya }\end{array}$ & $\begin{array}{r}6 \\
36 \\
\end{array}$ & $\begin{array}{l}37,5 \\
42,9\end{array}$ & $\begin{array}{l}10 \\
48\end{array}$ & $\begin{array}{l}62,5 \\
57,1\end{array}$ & $\begin{array}{l}16 \\
84\end{array}$ & $\begin{array}{l}100,0 \\
100,0\end{array}$ & $\begin{array}{c}\mathbf{0 , 8} \\
0,266-2,405\end{array}$ & 0,787 \\
\hline $\begin{array}{l}\text { Perilaku pengobatan: } \\
\text { - Buruk } \\
\text { - Baik }\end{array}$ & $\begin{array}{r}3 \\
39 \\
\end{array}$ & $\begin{array}{l}50,0 \\
41,5\end{array}$ & $\begin{array}{r}3 \\
55 \\
\end{array}$ & $\begin{array}{l}50,0 \\
58,5\end{array}$ & $\begin{array}{r}6 \\
94\end{array}$ & $\begin{array}{l}100,0 \\
100,0\end{array}$ & $\begin{array}{c}1,4 \\
0,270-7,358\end{array}$ & 0,694 \\
\hline $\begin{array}{l}\text { Jam tidur malam: } \\
->\text { jam } 22.00 \\
-<\text { jam } 22.00\end{array}$ & $\begin{array}{r}5 \\
37 \\
\end{array}$ & $\begin{array}{l}35,7 \\
43,0\end{array}$ & $\begin{array}{r}9 \\
49 \\
\end{array}$ & $\begin{array}{l}64,3 \\
57,0\end{array}$ & $\begin{array}{l}14 \\
86 \\
\end{array}$ & $\begin{array}{l}100,0 \\
100,0\end{array}$ & $\begin{array}{c}\mathbf{0 , 7} \\
0,228-2,379\end{array}$ & 0,772 \\
\hline $\begin{array}{l}\text { Kebiasaan sebelum tidur: } \\
\text { - Main di luar rumah } \\
\text { - Main di dalam rumah }\end{array}$ & $\begin{array}{l}15 \\
27 \\
\end{array}$ & $\begin{array}{l}42,9 \\
41,5 \\
\end{array}$ & $\begin{array}{l}20 \\
38 \\
\end{array}$ & $\begin{array}{l}57,1 \\
58,5 \\
\end{array}$ & $\begin{array}{l}35 \\
65 \\
\end{array}$ & $\begin{array}{l}100,0 \\
100,0 \\
\end{array}$ & $\begin{array}{c}1,0 \\
0,460-2,425\end{array}$ & 1,000 \\
\hline $\begin{array}{l}\text { Menghindari gigitan nyamuk: } \\
\text { - Tidak } \\
\text { - Ya }\end{array}$ & $\begin{array}{l}23 \\
19\end{array}$ & $\begin{array}{l}41,1 \\
43,2\end{array}$ & $\begin{array}{l}33 \\
25\end{array}$ & $\begin{array}{l}58,9 \\
56,8\end{array}$ & $\begin{array}{l}56 \\
44\end{array}$ & $\begin{array}{l}100,0 \\
100,0\end{array}$ & $\begin{array}{c}\mathbf{0 , 9} \\
0,412-2,040\end{array}$ & 0,841 \\
\hline $\begin{array}{l}\text { Keberadaan genangan air: } \\
\text { - Ya } \\
\text { - Tidak }\end{array}$ & $\begin{array}{l}30 \\
12 \\
\end{array}$ & $\begin{array}{l}41,1 \\
44,4 \\
\end{array}$ & $\begin{array}{l}43 \\
15 \\
\end{array}$ & $\begin{array}{l}58,9 \\
55,6 \\
\end{array}$ & $\begin{array}{l}73 \\
27 \\
\end{array}$ & $\begin{array}{l}100,0 \\
100,0\end{array}$ & $\begin{array}{c}\mathbf{0 , 9} \\
0,358-2,125\end{array}$ & 0,821 \\
\hline $\begin{array}{l}\text { Riwayat kontak penderita: } \\
\text { - Pernah } \\
\text { - Tidak }\end{array}$ & $\begin{array}{r}35 \\
7\end{array}$ & $\begin{array}{l}48,6 \\
25,0\end{array}$ & $\begin{array}{l}37 \\
21\end{array}$ & $\begin{array}{l}51,4 \\
75,0\end{array}$ & $\begin{array}{l}72 \\
27\end{array}$ & $\begin{array}{l}100,0 \\
100,0\end{array}$ & $\begin{array}{c}\mathbf{2 , 8} \\
1,073-7,503 \\
\end{array}$ & 0,042 \\
\hline Jumlah & 42 & 42,0 & 58 & 58,0 & 100 & 100,0 & & \\
\hline
\end{tabular}


Berdasarkan hasil analisis bivariat pada Tabel 3 dapat diketahui bahwa perilaku yang berhubungan dengan kejadian demam hanya pada variabel riwayat kontak dengan penderita malaria sebelumnya. Variabel yang lain tidak menunjukkan adanya hubungan yang bermakna secara signifikan.

\section{Endemisitas dan permasalahan malaria}

Menurut petugas malaria Dinas Kesehatan Provinsi Lampung, kasus malaria di Provinsi Lampung tidak termasuk dalam 10 besar penyakit dan secara endemisitas termasuk dalam kategori Low Case Incidence (LCl). Kabupaten yang memiliki tingkat endemisitas tertinggi adalah Kabupaten Pesawaran yang masuk dalam kategori Moderate Case Incidence (MCI) dengan Annual Parasite Incidence (API) sebesar $4,5 \%$. Namun menurut petugas provinsi, Kabupaten Pesawaran masuk kategori High Case Incidence $(\mathrm{HCl})$. Hasil konfirmasi dari laporan program malaria Passive Case Detection (PCD) diketahui bahwa API di Kabupaten Pesawaran tahun 2015 sebesar 6,5\% dan masuk dalam kategori High Case Incidence ( $\mathrm{HCl})$. Meskipun di wilayah Kabupaten Pesawaran khususnya di wilayah Puskesmas Hanura

termasuk daerah malaria tinggi, tetapi menurut informan malaria belum menjadi masalah yang mengganggu aktivitas penduduk.

Upaya penanggulangan malaria telah disampaikan pada kegiatan rapat koordinasi dengan lintas sektor maupun lintas program baik di tingkat provinsi, kabupaten, maupun kecamatan. Kegiatan penanggulangan malaria yang melibatkan lintas sektor difokuskan di Kabupaten Pesawaran yang merupakan daerah malaria tertinggi. Dukungan dari pemerintah daerah (pemda) khususnya pemda kabupaten belum optimal karena usulan kegiatan yang disampaikan dalam kegiatan rapat kerja tidak sepenuhnya difasilitasi. Kerja sama lintas sektor yang terbentuk hanya pada tingkat provinsi dan

kabupaten, sementara untuk tingkat puskesmas menurut informan belum ada kerja sama.

Kegiatan penanggulangan malaria telah dilakukan di daerah endemis malaria di wilayah Provinsi Lampung, khususnya di Kabupaten Pesawaran. Kegiatan yang dilakukan meliputi upaya pencegahan dan pendendalian. Upaya pencegahan yang dilakukan diantaranya penyemprotan rumah (Indoor Residual SprayingARS), larvasidasi, dan pembagian kelambu berinsektisida. Upaya penemuan dan pengobatan penderita dilakukan dengan Mass Blood Survey (MBS), yaitu pemeriksaan darah massal terhadap penduduk di daerah endemis yang ditindaklanjuti dengan kegiatan pengobatan penderita positif.

\section{BAHASAN}

Pemeriksaan pada ibu hamil dan balita dengan menggunakan metode RDT mendapatkan angka insiden sebesar 3\% yang terdiri dari dua orang ibu hamil dan satu balita. Hasil pemeriksaan tidak mendapatkan slide positif, hal ini kemungkinan karena ibu hamil dan balita tersebut sudah sembuh dari malaria karena sudah mendapatkan pengobatan. Berdasarkan hasil penelitian, penderita malaria yang diperiksa dengan menggunakan RDT masih dapat ditemukan adanya antigen histidine-rich protein II (HRP2) setelah hari ke 2-15 setelah pengobatan. ${ }^{9}$ Hal ini berarti penderita tersebut sebenarnya telah sembuh dari malaria, tetapi antigen malaria masih dapat dideteksi oleh RDT, meskipun secara mikroskopis sudah tidak ditemukan adanya Plasmodium.

Berdasarkan laporan dari Puskesmas Hanura, pada bulan Mei 2016 dilaporkan bahwa angka malaria positif per bulan Monthly Parasite Incidence/MoPI) di Puskesmas Hanura pada bulan Mei sebesar $3,1 \%$ dengan MoPI tertinggi di Desa Sukajaya Lempasing yang merupakan lokasi penelitian, yaitu sebesar $11,0 \%$, sedangkan angka malaria klinis per bulan (Monthly Malaria Incidence/MoMI) dilaporkan pada bulan Mei sebesar 12,2\%o dengan MoMI tertinggi juga ditemukan di Desa Sukajaya Lempasing sebesar 30,2\%o. Angka kasus malaria di wilayah Puskesmas Hanura pada tahun 2015 juga tinggi dan masuk kategori High Case Incidence $(\mathrm{HCl})$ karena memiliki AMI sebesar $120,8 \%$ dan API sebesar $65,6 \%$. Angka kasus malaria tertinggi pada tahun 2015 juga ditemukan di Desa Sukajaya Lempasing dengan AMI sebesar $294,2 \%$ dan API sebesar $170,1 \%{ }^{3}$

Kejadian malaria pada ibu hamil dan balita di wilayah Puskesmas Hanura relatif 
tinggi.Tahun 2015 dilaporkan kejadian malaria pada ibu hamil sebanyak 10 orang dan pada balita sebanyak 95 balita. Sementara sampai dengan bulan Mei 2015, jumlah kasus malaria pada ibu hamil sebanyak tiga orang dan pada balita sebanyak 47 balita. $^{3}$

Ibu hamil dan balita merupakan kelompok risiko tinggi untuk terjadinya kematian akibat malaria. ${ }^{10-12} \mathrm{Hal}$ ini juga terjadi di wilayah Puskesmas Hanura dengan ditemukannya kematian karena malaria pada ibu hamil pada tahun 2013 sehingga Puskesmas Hanura dinyatakan telah terjadi Kejadian Luar Biasa (KLB) malaria. $^{3}$

Risiko tinggi malaria pada ibu hamil karena malaria dapat mengakibatkan anemia yang disebabkan karena pecahnya sel darah merah yang terinfeksi maupun tidak terinfeksi. Risiko ibu hamil trimester pertama untuk menderita malaria berat semakin meningkat karena tidak dapat dilakukan pengobatan terhadap ibu hamil trimester pertama dengan pengobatan standar (Dihidroartemisinin + Piperaquine + Primaquine) yang digunakan saat ini. ${ }^{13}$

Penemuan penderita malaria secara dini pada ibu hamil dan bayi melalui skrining yang dilakukan secara rutin merupakan salah satu upaya untuk mencegah agar malaria tidak berkembang menjadi malaria berat. ${ }^{14}$ Skrining perlu dilakukan karena gejala klinis malaria pada ibu hamil seringkali tidak terlihat. ${ }^{15}$ Penelitian ini menemukan 3 responden positif malaria, sehingga dari hasil penelitian ini juga dapat memberikan manfaat secara langsung terhadap responden agar segera melakukan tindakan pengobatan untuk mencegah agar malaria tidak berkembang. Kegiatan skrining terhadap ibu hamil dan bayi dapat dilakukan secara rutin pada kegiatan posyandu sehingga bila ditemukan ibu hamil atau bayi yang positif malaria dapat segera diberi pengobatan sesuai standar. Kunjungan ibu hamil ke sarana kesehatan untuk memeriksakan kehamilan juga merupakan salah satu faktor pencegahan terhadap kejadian malaria berat pada ibu hamil. Ibu hamil yang sering memeriksakan kehamilannya di sarana kesehatan akan terkontrol sehingga apabila mengalami gejala malaria dapat segera dilakukan pemeriksaan. ${ }^{16}$ Selain itu juga ibu hamil tersebut terdata di sarana kesehatan setempat sehingga pada saat kegiatan pembagian kelambu dapat memperoleh kelambu untuk menghindari gigitan nyamuk. ${ }^{17}$

Pencegahan dan pengendalian malaria pada ibu hamil sangat penting. Salah satu upaya pencegahan malaria pada ibu hamil adalah dengan perilaku pencegahan gigitan nyamuk dengan penggunaan kelambu berinsektisida. Kegiatan pembagian kelambu berinsektisida kepada ibu hamil telah dilakukan di wilayah kerja Puskesmas Hanura. Namun, meskipun ibu hamil telah mendapatkan kelambu berinsektisida sebagai upaya pencegahan kontak dengan nyamuk, ibu hamil masih memiliki risiko untuk terkena malaria. Perilaku pencegahan kontak dengan nyamuk sebelum tidur juga perlu dipertimbangkan. ${ }^{18}$ Kegiatan pembagian kelambu telah dilakukan di beberapa daerah endemis malaria temasuk di Indonesia dalam upaya menanggulangi malaria khususnya pada ibu hamil dan balita. ${ }^{19}$ Hasil penelitian ini menunjukkan bahwa sebagian besar responden tidak melakukan upaya pencegahan gigitan nyamuk pada saat melakukan aktivitas sebelum tidur.

Pemeriksaan dini terhadap ibu hamil untuk diagnosis malaria juga perlu dilakukan untuk mencegah penyakit berkembang menjadi berat. ${ }^{20}$ Deteksi dini terhadap ibu hamil dan bayi dapat menurunkan risiko meningkatnya manifestasi malaria berat karena dengan ditemukannya penderita secara dini, maka penderita tersebut dapat segera diberi pengobatan.

Upaya pencegahan malaria pada ibu hamil dapat dilakukan dengan pemberian kemoprofilaksis anti malaria yang rutin, yaitu sulfadoxine-pyrimethamine ( $\quad \& \quad P)$. Pemberian kemoprofilaksis terbukti dapat mengurangi anemia dan menambah berat badan ibu hamil. Risiko dan bahaya malaria berat tidak meningkat selama kehamilan kedua pada wanita yang mendapat kemoprofilaksis. ${ }^{21}$

Risiko balita untuk menderita malaria berat juga lebih tinggi dibandingkan dengan kelompok umur lainnya. Hal ini karena penemuan dan pengobatan malaria pada kelompok umur ini yang relatif lebih sulit. ${ }^{22}$ Gejala klinis awal penderita malaria berupa demam merupakan gejala umum yang juga ditemukan pada penyakit lain. Diagnosis pasti untuk menentukan seseorang menderita malaria atau tidak adalah dengan 
pemeriksaan darah baik dengan RDT maupun mikroskopis. Keterbatasan sarana dan prasarana serta tenaga mikroskopis yang terampil juga merupakan kendala dalam penentuan atau diagnosis malaria secara pasti. Berdasarkan kebijakan Kementerian Kesehatan RI, pengobatan malaria saat ini sudah menggunakan obat baru, yaitu Artemisinin Combination Therapy (ACT). Pengobatan malaria dengan ACT harus berdasarkan hasil pemeriksaan darah, baik secara mikroskopis maupun dengan RDT. ${ }^{13}$ Efek samping penggunaan obat anti malaria dengan menggunakan ACT lebih berat dibandingkan dengan obat sebelumnya (klorokuin) sehingga menimbulkan penurunan kepatuhan minum obat khususnya balita yang menderita malaria. Efek samping berupa mual yang sering timbul akibat meminum obat ACT tersebut mengakibatkan dosis obat yang diberikan tidak sesuai karena tidak semua obat tertelan oleh balita.

Pengawasan minum obat malaria, khususnya balita yang menderita malaria sangat dibutuhkan agar balita yang menderita malaria dapat minum obat sesuai dosis sehingga dapat sembuh dari malaria serta tidak membahayakan bagi penderita malaria. $^{23}$ Hasil studi tentang angka kesembuhan malaria pada anak di Gabon telah dilakukan selama satu tahun (Juli 2004Juni 2005). Sebanyak 61 anak penderita malaria diberikan pengobatan dengan ACT dan dilakukan pemeriksaan pada hari ke-28 dengan menggunakan metode Polymerase Chain Reaction (PCR) untuk mengetahui adanya Plasmodium falciparum dalam darahnya setelah pengobatan. Hasil penelitian menunjukkan bahwa kelompok anak yang mendapat pengawasan minum obat memiliki angka kesembuhan 86\% (25 dari 29 anak; Cl 69-95\%), sedangkan pada anak yang tidak diawasi angka kesembuhannya sebesar $63 \%$ (20 dari 32 anak; $\mathrm{Cl} 45-77 \%$ ) dengan nilai $\mathrm{p}$ sebesar 0,04 . Hal ini menunjukkan bahwa terdapat perbedaan tingkat kesembuhan antara kelompok anak yang mendapat pengawasan minum obat dengan yang tidak mendapat pengawasan, dengan tingkat kesembuhan lebih tinggi pada kelompok anak yang mendapat pengawasan. ${ }^{24}$

Perilaku penggunaan kelambu pada ibu hamil dan balita menunjukkan proporsi yang cukup tinggi (84\%). Meskipun menurut informasi dari petugas Puskesmas Hanura seluruh ibu hamil dan balita telah mendapat kelambu, tetapi masih terdapat $16 \%$ ibu hamil dan balita yang tidak menggunakan kelambu. Perilaku penggunaan kelambu amat penting untuk mencegah ibu hamil dan balita kontak dengan nyamuk sehingga dapat mencegah penularan malaria. Tingkat pendidikan kepala keluarga memegang peranan penting dalam upaya peningkatan perilaku penggunaan kelambu. ${ }^{25}$ Hasil penelitian di Zambia menunjukkan bahwa tingkat pendidikan berpengaruh terhadap perilaku penggunaan kelambu. ${ }^{26}$

$$
\text { Perilaku pencarian pengobatan }
$$
berpengaruh terhadap perkembangan penyakit malaria. Penduduk yang sering melakukan pencarian pengobatan sendiri dan tidak ke sarana kesehatan memiliki risiko untuk terjadinya resistensi terhadap obat anti malaria. Hal ini karena pengobatan yang dilakukan sendiri tidak sesuai dengan dosis sehingga tidak menghilangkan seluruh Plasmoodium yang ada di dalam darahnya. Perilaku pengobatan ibu hamil dan balita dalam penelitian ini sebagian besar menunjukkan perilaku baik, yaitu berobat ke puskesmas atau bidan desa. Hasil penelitian di wilayah Kota Palu mendapatkan bahwa perilaku masyarakat dalam pencarian pengobatan cukup baik, yaitu dengan melakukan pengobatan ke sarana kesehatan. Namun demikian masih ditemukan adanya kepercayaan tentang penyebab sakit dan cara penyembuhan penyakit yang berdasarkan aturan adat. ${ }^{27}$ Salah satu strategi dalam penanggulangan malaria dapat dilakukan dengan cara pendekatan terhadap tokoh adat setempat. Hal ini karena tingkat kepercayaan masyarakat terhadap tokoh adat yang masih relatif tinggi. Penyampaian informasi tentang malaria, khususnya yang berkaitan dengan upaya pengenalan dan penemuan penderita (gejala malaria), pengobatan serta pencegahan dapat dilakukan melalui tokoh adat setempat. Upaya kegiatan pengobatan massal untuk pencegahan penularan malaria di daerah endemis tinggi juga perlu dilakukan terutama pada puncak penularan. ${ }^{28}$ Kegiatan tersebut dimaksudkan untuk mencegah terjadinya Kejadian Luar Biasa (KLB) malaria.

Keberadaan genangan air di sekitar rumah dapat meningkatkan risiko tertular malaria. Genangan air merupakan tempat berkembangbiak nyamuk penular malaria. 
Hasil studi sebelumnya yang dilakukan di lokasi penelitian mendapatkan bahwa lingkungan fisik (tempat perkembangbiakan nyamuk) dan perilaku (penggunaan kawat kasa, pemakaian obat nyamuk, ke luar rumah malam hari) merupakan faktor risiko malaria. ${ }^{29}$

Penelitian yang dilakukan di daerah endemis malaria di Kalimantan Selatan mendapatkan bahwa faktor lingkungan berupa rawa-rawa dan kondisi kandang ternak yang dekat dengan pemukiman memicu adanya tempat perkembangbiakan vektor malaria sehingga menghambat upaya masyarakat dalam pencegahan malaria. ${ }^{30}$

Penularan malaria terjadi karena adanya interaksi antara sumber penular (agent), nyamuk sebagai vektor dan inang (host), baik orang sehat maupun sakit. Keberadaan orang sakit malaria di suatu daerah dapat menjadi sumber penular malaria bagi penduduk di sekitarnya. ${ }^{31}$ Hasil penelitian ini menunjukkan bahwa terdapat hubungan antara riwayat kontak dengan penderita malaria dengan riwayat demam yang merupakan gejala klinis awal malaria. Selain itu, malaria juga dapat menular melalui plasenta sehingga ibu hamil yang menderita malaria perlu segera diobati. ${ }^{32}$

\section{KESIMPULAN}

Angka kejadian malaria pada penelitian ini sebesar $3 \%$ dengan penderita positif ditemukan pada dua orang ibu hamil dan satu balita. Balita yang diperiksa sebanyak 64 balita dengan umur 0-4 tahun, sedangkan ibu hamil yang diperiksa sebanyak 36 orang dengan usia termuda 16 tahun dan tertua 46 tahun. Variabel yang berhubungan dengan malaria adalah riwayat kontak dengan penderita. Upaya pengendalian yang telah dilakukan diantaranya penyemprotan rumah, larvasidasi, pembagian kelambu terhadap ibu hamil dan balita.

\section{SARAN}

Berdasarkan kesimpulan tersebut, maka perlu dilakukan upaya pemeriksaan secara dini terhadap ibu hamil dan balita yang menderita demam agar dapat terdeteksi sedini mungkin bila menderita malaria serta dapat diberi tindakan pengobatan secara cepat. Bila ditemukan penderita malaria di sekitar ibu hamil atau balita, maka perlu upaya preventif dengan penggunaan kelambu pada pada saat tidur dan penggunaan obat anti nyamuk sebelum tidur terhadap ibu hamil dan balita agar tidak tertular malaria dengan perlindungan terhadap gigitan nyamuk vektor malaria.

\section{KONTRIBUSI PENULIS}

Kontribusi penulis pada artikel ini yaitu, kontributor utama adalah $\mathrm{Sn}, \mathrm{IM}$, MA dan RN.

\section{UCAPAN TERIMA KASIH}

Ucapan terima kasih disampaikan kepada: Kasnodihardjo dan Bambang Sukana, sebagai reviewer yang telah membimbing dalam pembuatan protokol dan penyusunan serta penulisan laporan penelitian; Inswiansri, yang telah memberikan pembinaan dalam penyusunan laporan akhir, Kepala Dinas Kesehatan Provinsi Lampung dan Kepala Dinas Kesehatan Kabupaten Pesawaran, berserta semua staf yang telah membantu selama pelaksanaan penelitian.

\section{DAFTAR PUSTAKA}

1. WHO. World Malaria Report 2017. Geneva: World Health Organization; 2017.

2. Dinkes Kab. Pesawaran. Laporan Penemuan Dan Pengobatan Malaria Di Kabupaten Pesawaran Tahun 2015. Gedung Tataan; 2016.

3. Puskesmas Hanura. Laporan Bulanan Malaria Puskemas Hanura, Bulan Mei Tahun 2016. Hanura; 2016.

4. Faradila, Ishak $\mathrm{H}$ MH. Penggunaan Kelambu berinsektisida Terhadap Pengendalian Penyakit Malaria di Bonto Bahari. Repiratory. http://repository.unhas.ac.id/bitstream/ handle/123456789/10520/FARADILA K11110001. pdf?sequence $=1$. Published 2014.

5. Rahmadiliyani N, Noralisa. Hubungan penggunaan kelambu berinsektisida dan kejadian malaria di Desa Teluk Kepayang Kecamatan Kusan Hulu Kabupaten Tanah Bumbu Tahun 2013. J Buski. 2013;4(3):128-132.

6. Saikhu A. Faktor Risiko Lingkungan dan Perilaku yang Mempengaruhi Kejadian Kesakitan Malaria di Provinsi 
Sumatera Selatan (Analisis Lanjut Data Hasil Riset Kesehatan Dasar 2007). Aspirator. 2011;3(1):8-13.

7. Olupot PO, Eregu EIE, Naizuli K, Ikiror $\mathrm{J}$, Acom L, Burgoine K. Neonatal and congenital malaria: a case series in malaria endemic eastern Uganda. Malar J. 2018;17(171):1-5. doi:10.1186/s12936-018-2327-0.

8. Sugiarto. Teknik Sampling. Jakarta: PT Gramedia Pustaka Utama; 2003.

9. Dalrymple U, Arambepola R, Gething PW, Cameron E. How long do rapid diagnostic tests remain positive after anti - malarial treatment? Malar J. 2018;17(228):1-13.

doi:10.1186/s12936-018-2371-9.

10. Willilo RA, Molteni F, Mandike R, et al. Pregnant women and infants as sentinel populations to monitor prevalence of malaria: results of pilot study in Lake Zone of Tanzania. Malar $J$. 2016;15(392):1-10. doi:10.1186/s12936-016-1441-0.

11. Sumari $D$, Mwingira $F$, Selemani $M$, Mugasa J, Mugittu K, Gwakisa P. Malaria prevalence in asymptomatic and symptomatic children in Kiwangwa , Bagamoyo district , Tanzania. Malar J. 2017;16(222):1-7. doi:10.1186/s12936-017-1870-4.

12. Wanzira $H$, Katamba $H$, Okullo $A E$, Agaba B, Kasule M, Rubahika D. Factors associated with malaria parasitaemia among children under 5 years in Uganda: a secondary data analysis of the 2014 Malaria Indicator Survey dataset. Malar J. 2017;16(191):1-9.

doi:10.1186/s12936-017-1847-3.

13. Depkes RI. Pedoman Penatalaksanaan Kasus Malaria Di Indonesia. Jakarta: Direktorat Jenderal P2PL, Depkes RI; 2009.

14. Nkoka O, Chuang TW, Chen YH. Association between timing and number of antenatal care visits on uptake of intermittent preventive treatment for malaria during pregnancy among Malawian women. Malar J. 2018;17(211):1-11. doi:10.1186/s12936-018-2360-z.

15. Tahita MC, Tinto $\mathrm{H}$, Menten $\mathrm{J}$, et al. Clinical signs and symptoms cannot reliably predict Plasmodium falciparum malaria infection in pregnant women living in an area of high seasonal transmission. Malar J. 2013;12(464):17.

16. Awantang GN, Babalola SO, Koenker $\mathrm{H}$, Fox KA, Toso $M$, Lewicky $N$. Malaria - related ideational factors and other correlates associated with intermittent preventive treatment among pregnant women in Madagascar. Malar J. 2018;17(176):110. doi:10.1186/s12936-018-2308-3.

17. Salomão C, Sacarlal J, Gudo ES. Assessment of coverage of preventive treatment and insecticide - treated mosquito nets in pregnant women attending antenatal care services in 11 districts in Mozambique in 2011: the critical role of supply chain. Malar J. 2017;16(223):1-8.

doi:10.1186/s12936-017-1872-2.

18. Fuge TG, Ayanto SY, Gurmamo FL. Assessment of knowledge, attitude and practice about malaria and ITNs utilization among pregnant women in Shashogo. Malar J. 2015;14(435):1-9. doi:10.1186/s12936-015-0755-7.

19. Koenker $\mathrm{H}$, Yukich JO. Effect of user preferences on ITN use: $A$ review of literature and data. Malar J. 2017; 16(233):1-18. doi:10.1186/s12936-017-1879-8.

20. Cohee LM, Kalilani-phiri L, Boudova S et al., Cohee LM, Kalilani-Phiri L, et al. Submicroscopic malaria infection during pregnancy and the impact of intermittent preventive treatment. Malar J. 2014;13(1):1-9. doi:10.1186/1475-2875-13-274.

21. Fokam EB, Ngimuh L, Kimbi JKA, Wanji S. Assessment of the usage and effectiveness of intermittent preventive treatment and insecticide - treated nets on the indicators of malaria among pregnant women attending antenatal care in the Buea Health District , Cameroon. Malar J. 2016;15(172):1-7. doi:10.1186/s12936-016-1228-3.

22. Indriaty I, Bule P, Patanduk Y. Malaria pada Anak di Bawah Umur Lima. J Vektor Penyakit. 2015;9(2):65-71.

23. Ntamabyaliro NY, Burri C, Nzolo DB, et al. Drug use in the management of uncomplicated malaria in public health 
facilities in the Democratic Republic of the Congo. Malar J. 2018;17(189):1-8. doi:10.1186/s12936-018-2332-3.

24. Oyakhirome S, Pötschke M, Schwarz NG, et al. Artesunate--amodiaquine combination therapy for falciparum malaria in young Gabonese children. Malar J. 2007;6:29. doi:10.1186/14752875-6-29.

25. Sabin L, Hecht EMS, Brooks MI, et al. Prevention and treatment of malaria in pregnancy: what do pregnant women and health care workers in East India know and do about it? Malar J. 2018;17(207):1-13. doi:10.1186/s12936-018-2339-9.

26. Sichande $M$, Michelo $C$, Halwindi $H$, Miller J. Education attainment of head of households associated with insecticide-treated net utilization among five to nineteen-year old individuals: evidence from the malaria indicator survey 2010 in Zambia. Malar J. 2014;13:378. doi:10.1186/14752875-13-378.

27. Ningsi, Erlan A, Puryadi. Aspek Sosial Budaya dan Lingkungan Fisik Masyarakat Suku Da'a dalam Kaitannya dengan Kejadian Malaria di Wilayah Kota Palu Sulawesi Tengah. Media Litbang Kesehat. 2009;21(1):18-31.
28. Pell C, Tripura R, Nguon C, et al. Mass anti - malarial administration in western Cambodia: a qualitative study of factors affecting coverage. Malar $J$. 2017;16(206):1-11. doi:10.1186/s12936-017-1854-4.

29. Sulistianingsih E. Hubungan Faktor Lingkungan Fisik dan Perilaku Dengan Kejadian Malaria di Wilayah Kerja Puskesmas Hanura Kecamatan Padang Cermin Kabupaten Pesawaran tahun 2010. J Kesehat. 2010;I(2):191-196.

30. Suharjo. Pengetahuan Sikap dan Perilaku MAsyarakat tentang Malaria di Daerah Endemis Kalimantan Selatan. Media Litbang Kesehat. 2015;25(1):23-32.

31. Guerra M, Sousa B De, Mabale NN, Berzosa P, Arez AP. Malaria determining risk factors at the household level in two rural villages of mainland Equatorial Guinea. Malar J. 2018;17(203):1-10. doi:10.1186/s12936-018-2354-x.

32. Stephens JK, Baafour EK, Dickson EK, et al. Effect of IPTp on Plasmodium falciparum antibody levels among pregnant women and their babies in a sub - urban coastal area in Ghana. Malar J. 2017;16(224):1-10. doi:10.1186/s12936-017-1857-1. 